\title{
Malignant intraperitoneal mesothelioma-Başkent University experience
}

\author{
Malign intraperitoneal mezotelioma - Başkent Üniversitesi deneyimi
}

\author{
Ronalds Macuks ${ }^{1,2}$, Halis Özdemir ${ }^{3}$, Polat Dursun³, Özlem Işıksaçan Özen', Nihan Haberal', Ali Ayhan ${ }^{3}$ \\ ${ }^{\prime}$ Riga Stradins University, Riga, Latvia \\ ${ }^{2}$ Department of Gynecological Oncology, Riga Eastern Clinical University Hospital, Riga, Latvia \\ ${ }^{3}$ Department of Gynecology and Obstetrics, Faculty of Medicine, Basskent University Ankara Hospital, Ankara, Turkey \\ ${ }^{4}$ Department of Pathology, Faculty of Medicine, Basskent University Ankara Hospital, Ankara, Turkey
}

\section{Abstract}

Objective: To evaluate diagnostic and treatment results of malignant intraperitoneal mesothelioma in one setting.

Materials and Method: 12 patients treated for malignant peritoneal mesothelioma from January 2007 to June 2009 in Başkent University Ankara Hospital, Department of Gynaecology and Obstetrics were evaluated. In a retrospective observational study design tumour stage, grade, differentiation, time from first symptoms, pleural involvement, peritoneal cancer index, surgical cytoreduction, chemotherapeutic regimen, number of cycles, disease free survival and overall survival were evaluated. Disease free survival, overall survival, time until first symptoms were researched.

Results: The main presenting symptom was abdominal distension. Primary cytoreductive surgery followed by chemotherapy was performed in 9 patients. In 6 patients completeness of cytoreductive score below 2 was achieved. As a first line chemotherapy the most often used was cisplatin in combination with pemetrexed. Themean time from first symptoms until the diagnosis was 1.9 months. Disease free survival of $4.4 \pm 1.0$ months after completing particular treatment and overall 1-year survival of $85.7 \%$ was observed. No correlations between first symptoms $(0.27, \mathrm{p}=0.52)$, time until the diagnosis $(-0.29$, $\mathrm{p}=0.44)$ and overall survival were observed. Similarly, correlations between peritoneal cancer index $(0.25, \mathrm{p}=0.67)$, prior surgical score $(-.45, \mathrm{p}=0.37)$, completeness of cytoreduction score $(0.61, \mathrm{p}=0.27)$ and overall survival were not observed.

Conclusions: Because of the low number of patients and different treatment approaches data from a particular patient setting are inconclusive, but from the literature there is evidence that patients with malignant intraperitoneal mesothelioma should undergo optimal cytoreduction and receive a combination of cisplatin and pemetrexed as a first line chemotherapy for intravenous or cisplatin in different chemotherapy regimens using the intraperitoneal administration route, if accessible, with even higher overall survival rates.

(J Turkish-German Gynecol Assoc 2011; 12: 104-9)

Key words: Mesothelioma, intraperitoneal

Received: 28 February, 2011

Accepted: 23 March, 2011

\section{Özet}

Amaç: Tek bir merkezde malign intraperitoneal mezoteliomanın tanı ve tedavi sonuçlarını değerlendirmek.

Gereç ve Yöntemler: Başkent Üniversitesi Ankara Hastanesi, Kadın Hastalıkları ve Doğum Departmanında Ocak 2007 - Haziran 2009 arasında malign peritoneal mezotelioma için tedavi edilmiş 12 hasta çalışmaya alındı. Retrospektif gözlemsel çalışma dizaynında tümör evresi, derecesi, farklılaşması, ilk semptomlardan beri geçen süre, plevral tutulum, peritoneal kanser indeksi, cerrahi hücre azaltımı, kemoterapötik rejim, tedavi döngülerinin sayısı, hastalıksız sağkalım ve toplam sağkalım değerlendirildi. Hastalıksız sağkalım, toplam sağkalım, ilk semptomlara kadar geçen süre araştırıldı.

Bulgular: Başlıca başvuru semptomu karında şişkinlikti. Kemoterapinin izlediği birincil sitoredüktif cerrahi 9 hastada gerçekleştirildi. 6 hastada 2'nin altında sitoredüktif tamlığı skoruna ulaşıldı. İlk seçenek kemoterapi olarak en sık kullanılan pemetreksed ile kombinasyonda sisplatin idi. İlk semptomlardan tanıya kadar geçen ortalama süre 1.9 aydı. Belirli tedavinin tamamlanmasından sonra hastalıksız sağkalım $4.4 \pm 1.0$ ay ve toplam 1 -ylllık sağkalım $\% 85.7$ olarak gözlendi. Toplam sağ kalım ile ilk semptomlar $(0.27, \mathrm{p}=0.52)$ ve tanıya kadar geçen süre $(-0.29, p=0.44)$ arasında korelasyon gözlenmedi. Benzer şekilde, toplam sağ kalım ile peritoneal kanser indeksi $(0.25, \mathrm{p}=0.67)$, önceki cerrahi skoru (-.45, p=0.37), sitoredüksiyon tamlığı skoru $(0.61, \mathrm{p}=0.27)$ arasında korelasyon gözlenmedi.

Sonuçlar: Düşük hasta sayısı ve farklı tedavi yaklaşımları nedeniyle bu özel hasta grubundan gelen veriler bir sonuca ulaşmamıştır, fakat literatürde malign intraperitoneal mezoteliomalı hastaların optimal sitoredüksiyon geçirmesi ve ilk seçenek kemoterapi olarak intravenöz sisplatin ve pemetreksed alması veya eğer mümkünse, daha yüksek toplam sağ kalım oranları ile, intraperitoneal uygulama yolunu kullanan farklı kemoterapi rejimlerinde sisplatin alması gerektiğine dair kanitlar bulunmaktadır

(J Turkish-German Gynecol Assoc 2011; 12: 104-9)

Anahtar kelimeler: Mezotelioma, intraperitoneal

Geliş Tarihi: 28 Şubat 2011

Kabul Tarihi: 23 Mart 2011 


\section{Introduction}

Primary malignant peritoneal mesothelioma is a rare tumour with a poor prognosis. Mesotheliomas are strongly associated to asbestos exposure, but only $50 \%$ of patients having peritoneal mesotheliomas have been exposed to asbestos $(1,2)$. In some parts of Europe, the processing of asbestos reached its peak in the middle of the 1980s, therefore a rising number of cases is expected until 2020. The highest incidence of mesotheliomas is observed in Australia, The Netherlands, United Kingdom and Italy, varying from 33-22 cases per million (3). The overall prevalence is 1-2 cases per million. Mostly the tumour arises from mesothelial cells in the pleura, while primary malignant mesotheliomas in the abdominal cavity comprise between 10 to $40 \%$ (4-8).

Regardless of the site of origin, the prognosis is usually poor, with a median survival of 4-12 months for pleural tumours and less than 1 year for peritoneal tumours $(9,10)$. Successful treatment is based on early diagnosis and appropriate treatment which embraces optimal tumour debulking procedure, especially from surfaces of the parietal peritoneum, and chemotherapy. It is thought that completeness on the cytoreduction score is one of the most important prognostic factors for the treatment of malignant peritoneal mesothelioma. The overall response rate reported with a single agent chemotherapy, combined chemotherapy, intraperitoneal chemotherapy, continuous hyperthermic peritoneal perfusion are $13.1 \%, 20.5 \%, 47.4 \%$, and $84.6 \%$, respectively (11). Cisplatin is the most studied agent, with activity in $25 \%$ of patients (12).

The present paper reports 12 cases of malignant primary peritoneal mesothelioma who were treated by debulking surgery and systemic chemotherapy in one institution.

\section{Material and Methods}

The electronic data base at the Baskent University Hospital from January 2005 to June 2009 was reviewed retrospectively for malignant peritoneal mesothelioma and included in this study. All consecutive patients with intraperitoneal mesothelioma were included in the study. Only cases with a definitive diagnosis of peritoneal malignant mesothelioma were included. Cases were accepted as mesothelioma if the light microscopy, imunohistochemistry, and clinical/surgical findings were fully consistent with the diagnosis. Benign mesothelial lesions, such as adenomatoid tumour, well-differentiated papillary mesothelioma, localized fibrous tumours, and multicystic mesothelioma were not included the study. The staging system for malignant peritoneal mesotheliomas proposed by Sebbag and Sugarbaker was selected and in most cases tumour differentiation was reported as belonging to one of three-adonomucious, epithelial and biphasic or sarcomatous type (13). Cases with uncertain diagnosis and indistinct imunohistochemistry profile were re-evaluated by a pathologist. Finally, a total of 12 peritoneal malignant mesothelioma cases were found to be eligible to enter the study. For tumour spread and completeness of cytoreductive surgery, patients were divided as having peritoneal cancer index (PCI) above or below 28 and completeness of cytoreduction (CC) denoted with a single score from 0 to 3 . The completeness of cytoreduction score is defined as follows: score " 0 " indicates that no visible peritoneal carcinomatosis remains after cytoreduction; score " 1 " indicates that tumour nodules persisting after cytoreduction are less than $2.5 \mathrm{~mm}$; score "2" indicates tumour nodules between $2.5 \mathrm{~mm}$ and 2.5 $\mathrm{cm}$ and score " 3 " indicates tumour nodules greater than $2.5 \mathrm{~cm}$ or a confluence of unresected tumour nodules at any site within the abdomen or pelvis.

Presence or absence of disease involving the pleural cavity was determined by computer tomography. Thickened pleura above $10 \mathrm{~mm}$ or pleural effusion cytologicaly approved for malignancy were considered as having concomitant pleural disease. Overall survival (OS) was considered as a primary endpoint of the study, as secondary endpoints were disease free survival (DFS) and time from first symptoms. In some cases, it was impossible to assess disease free survival, because patients were followed up in other institutions and departments in Turkey.

Prior surgery score was assessed as a complete count of surgeries for a particular patient and evaluated for correlations with survival parameters.

All of the patients included in the analysis received only systemic chemotherapy.

For data collection and calculations SPSS 17.0 was used. Correlation analysis between patients with peritoneal cancer index above and below 28, cytoreductive score, disease free, overall survival and surgical procedures was analyzed with the nonparametric Spearman's correlation test. For correct nonparametric correlation analysis, overall survival of patients was ranged according to those who survived more and less than one year, similarly ranging was performed for correct application of disease free survival-patients were divided in those who had disease free survival more or less than 5 months. Correlation among time from first symptoms, time to diagnosis and overall survival was assessed with parametrical Pearson's correlation test. Statistically significant difference was accepted at level of 0.05 .

\section{Results}

The age range for the patients was $26-69$ years with a mean age of 57 years.

Abdominal distension was the first and most often observed symptom when patients presented to hospital or outpatient unit. Mean time from first symptoms until the diagnosis was $1.9 \pm 0.6$ months with a range from $0-4.5$ months. No correlations between first symptoms $(0.27, \mathrm{p}=0.52)$, time until the diagnosis $(-0.29, \mathrm{p}=0.44)$ and overall survival were observed.

Histologically, the majority of mesotheliomas were epitheloid (tubulopapillary) (10/12) with only one patient having mesothelioma of mixed subtype and one patient with biphasic subtype. For completeness of optimal tumour debulking, such procedures as colostomy and splenectomy were performed for several patients. Parietal stripping of the peritoneum was carried out on only one patient (Table 1). There was no correlation observed between survival parameters and splenectomies $(0.17, \mathrm{p}=0.72)$. Correlation for colostomies was not possible to assess because 
Table 1. Characteristics of serum biomarker levels, tumor dissemination, management and survival for patients included in the study

\begin{tabular}{|c|c|c|c|c|c|c|c|c|c|c|c|}
\hline $\begin{array}{l}\text { Patient } \\
\text { number }\end{array}$ & Age & $\begin{array}{c}\text { Ca-125, } \\
\mathrm{U} / \mathrm{ml}\end{array}$ & PCI & $\mathrm{CC}$ & Surgery & Histology & $\begin{array}{l}\text { Pleural } \\
\text { disease }\end{array}$ & $\begin{array}{c}\text { First line } \\
\text { Chemotherapy }\end{array}$ & $\begin{array}{l}\text { DFS, } \\
\text { months }\end{array}$ & $\begin{array}{c}\text { Alive } \\
\text { or Dead }\end{array}$ & $\begin{array}{c}\text { OS, } \\
\text { months }\end{array}$ \\
\hline 1 & 60 & 106.0 & $>28$ & 1 & $\begin{array}{c}\text { Hysterectomy+BSO+ } \\
\text { BPPLND+Omentectomy }\end{array}$ & Epitheloid & Yes & $\begin{array}{l}\text { Cisplatin+ } \\
\text { Pemetrexed }\end{array}$ & 4.0 & Dead & 13.5 \\
\hline 2 & 54 & 398.0 & $>28$ & 2 & $\begin{array}{c}\text { Hysterectomy+BSO+ } \\
\text { BPPLND+Omentectomy+ } \\
\text { Appendectomy }\end{array}$ & Epitheloid & Yes & $\begin{array}{l}\text { Cisplatin+ } \\
\text { Pemetrexed }\end{array}$ & 7.0 & Alive & 23.0 \\
\hline 3 & 67 & 696.2 & $>28$ & 2 & $\begin{array}{c}\text { Hysterectomy+BSO+ } \\
\text { BPPLND+Omentectomy+ } \\
\text { Appendectomy }\end{array}$ & Epitheloid & No & $\begin{array}{c}\text { Cisplatin+ } \\
\text { Gemcitabine }\end{array}$ & 0.0 & Dead & 3.0 \\
\hline 4 & 26 & 40.2 & $<28$ & 1 & BPPLND+Omentectomy* & NA & NA & $\begin{array}{c}\text { Cisplatin+ } \\
\text { Gemcitabine }\end{array}$ & 7.0 & Alive & 13.5 \\
\hline 5 & 54 & 55.0 & $>28$ & 2 & $\begin{array}{c}\text { Hysterectomy+BSO+ } \\
\text { BPPLND+Omentectomy+ } \\
\text { Appendectomy+Splenectomy }\end{array}$ & Epitheloid & Yes & NA & NA & NA & NA \\
\hline 6 & 59 & NA & NA & & $\begin{array}{c}\text { Hysterectomy+BSO+ } \\
\text { BPPLND+Omentectomy }\end{array}$ & Mixed & Yes & $\begin{array}{l}\text { Carboplatin+ } \\
\text { Paclitaxel }\end{array}$ & 7.0 & Dead & 60.0 \\
\hline 7 & 64 & 35.6 & $>28$ & 2 & $\begin{array}{c}\text { Hysterectomy+BSO+ } \\
\text { Omentectomy+Appendectomy }\end{array}$ & Epitheloid & Yes & NA & NA & NA & NA \\
\hline 8 & 66 & 24.0 & $>28$ & 2 & $\begin{array}{c}\text { Hysterectomy+BSO+ } \\
\text { BPPLND+Omentectomy+ } \\
\text { Appendectomy+Colostomy }\end{array}$ & Epitheloid & No & $\begin{array}{c}\text { Gemcitabine+ } \\
\text { Carboplatin }\end{array}$ & NA & NA & NA \\
\hline 9 & 52 & 74.0 & $>28$ & 1 & $\begin{array}{c}\text { Hysterectomy+BSO+ } \\
\text { BPPLND+Omentectomy+ } \\
\text { Appendectomy+Peritonectomy }\end{array}$ & Epitheloid & No & Refused & 3.0 & Alive & 20.0 \\
\hline 10 & 68 & 4.4 & $>28$ & 1 & $\begin{array}{c}\text { Hysterectomy+BSO+ } \\
\text { BPPLND+Omentectomy+ } \\
\text { Appendectomy+Splenectomy }\end{array}$ & NA & NA & $\begin{array}{l}\text { Carboplatin+ } \\
\text { Paclitaxel }\end{array}$ & NA & Alive & 3.0 \\
\hline 11 & 56 & 6.5 & $>28$ & 1 & $\begin{array}{c}\text { Hysterectomy+BSO+ } \\
\text { Omentectomy+Appendectomy } \\
+ \text { Splenectomy }\end{array}$ & Epitheloid & No & $\begin{array}{c}\text { Capecitebine+ } \\
\text { Oxaliplatin }\end{array}$ & 3.0 & Alive & 12.0 \\
\hline 12 & 69 & 99.5 & $>28$ & 1 & $\begin{array}{c}\text { Hysterectomy+BSO+ } \\
\text { Omentectomy+Colostomy } \\
+ \text { Splenectomy }\end{array}$ & Biphasic & No & $\begin{array}{l}\text { Cisplatin+ } \\
\text { Pemetrexed }\end{array}$ & NA & Alive & 0.5 \\
\hline
\end{tabular}

patients who had colostomies had a too short follow-up period. To evaluate the result of chemotherapy for one patient explorative laparotomy was performed and for three patients secondary tumour mass debulking surgery was done.

Most patients admitted to the hospital were late stage with wide tumour dissemination and a peritoneal cancer index above 28. Only one patient had a peritoneal cancer index below 28 . According to the TGM staging system proposed by Sebbag and Sugarbaker patients were staged as follows -1 patient stage II, 4 with stage III, 5 patients stage IV and for two patients there was unknown lymph node status, but regarding the extent of the disease, they were both stage III or IV. In 6 patients completeness of cytoreductive score below 2 was achieved. After completing of surgery, 5 patients did not have any evidence of metastases, for 2 patients it was not possible to asses the presence of metastases, 2 patients had parenchymal liver metastases, 1 patient had pelvic lymphnode metastases and 2 patients had paraaortic lymphnode metastases. There were 4 patients with a prior surgery score of two; all other patients had surgery only once. Correlations between peritoneal cancer index $(0.25$, $\mathrm{p}=0.67)$, prior surgical score $(-0.45, \mathrm{p}=0.37)$, completeness of cytoreduction score $(0.61, \mathrm{p}=0.27)$ and overall survival were not observed.

For three patients neoadjuvant chemotherapy was given and tumour debulking surgery was performed after the third cycle For three patients cisplatin in combination with Pemetrexed (ALIMTA, manufactured by Eli Lilly and Company, Indianapolis, United States) was given as a first line chemotherapy. For two 
patients cisplatin in combination with gemcitabine was given as a first line chemotherapy. For three patients chemotherapy was not completed - one discontinued because of poor performance status, one patient refused and one died after the fifth cycle of gemcitabine and carboplatin. One patient received second line chemotherapy of cisplatin and gemcitabine following the first line chemotherapy of cisplatin and pemetrexed and for one patient chemotherapy was repeated six times with 6 cycles each time. For the last patient, cisplatin with paclitaxel was given as a first line chemotherapy, six cycles of topotecan was received in a second line chemotherapy; etoposide, docetaxel and liposomal doxorubicin were applied as third line chemotherapy agents. Then chemotherapy was continued with carboplatin and liposomal doxorubicin, then gemcitabine as a single agent and after that cisplatin with pemetrexed. As a palliative chemotherapy cyclophosphamide $50 \mathrm{mg}$ a day with metotrexate $2.5 \mathrm{mg} 2$ days a week was ordinated. Overall survival of a particular patient was 100 months.

Information regarding the clinical outcome was available for 9 of our 12 cases, with a mean disease free survival of $4.4 \pm 1.0$ months after completing a particular treatment and 1-year overall survival of $85.7 \%$.

By the end of the study three patients were dead and six were still alive.

\section{Discussion}

Malignant mesothelioma of the peritoneum is a rare disease. Despite the fact that there are no specific symptoms for malignant peritoneal mesothelioma, in the literature similar data for occurrence of abdominal distension in $56 \%$ of patients suffering from malignant peritoneal mesothelioma have been reported (14). Abdominal distension was also the most commonly observed symptom, accounting for $75.0 \%$ in our study. Manzini reported patients complaining most often about abdominal pain, comprising $35 \%$ of patients (15). We observed abdominal pain in $58.3 \%$ of our patients and for one third of patients abdominal pain was observed together with abdominal distension. Ascitis was observed in a very high proportion of patients $-81.8 \%$, whereas in the literature there are reports of ascitic collection in $36-90 \%$ of cases (16-18). This difference may be explained by an investigation method and the amount of abdominal fluid to be considered as pathologic. According to our data, mean time from first symptoms to diagnosis was 1.9 months. Other authors have reported a time interval of 122-180 days from first symptoms $(15,16)$. Those data indicate a rather large time interval between first symptoms and diagnosis, therefore there is still a place to improve diagnostic techniques that would lead to faster diagnostic and better cure rates.

The small number of cases precludes a uniform therapeutic approach (19). The most common treatment strategy for peritoneal mesothelioma involves a multimodality approach with surgical debulking followed by systemic and/or intraperitoneal chemotherapy. It has been observed that completeness of cytoreductive score below 2 is associated with improved survival and it is the most significant prognostic factors (13). In our study completeness of cytoreduction score below 2 was achieved for
6 patients, but no benefit or improved survival was observed over these who had cytoreductive score for completeness of 2 or higher $(0.61, \mathrm{p}=0.27$ for OS and $-0.25, \mathrm{p}=0.63$ for DFS). There are reports that all patients with lymph node metastases die within 2 years (20). In our study 5 patients had lymphatic or parenchymal metastases. Two of them died, two patients are alive after 20 and 23 months following the diagnosis and there is no information about one other patient who had lymph node metastases.

Regardless of improved survival rates of hyperthermic intraperitoneal chemotherapy, systemic chemotherapy is still given in most oncogynaecologic centres. For three patients neoadjuvant chemotherapy was given and tumour debulking surgery was performed after the third cycle. For one patient neoadjuvant chemotherapy of carboplatin and paclitaxel was given because this case was misdiagnosed as bulky ovarian cancer. Cisplatin in combination with pemetrexed was applied as a first line chemotherapy for three patients, nonetheless no particular chemotherapy regimen correlated with prolonged disease free survival $(0.09, p=0.85)$ or overall survival $(0.26, p=0.58)$ when compared to other chemotherapy regimens. In the literature, the response rates are significantly higher for patients treated with the pemetrexed in combination than for patients treated with cisplatin alone $(41 \%$ versus $17 \%, \mathrm{p}<0.0001)$. Patients treated with pemetrexed and cisplatin have also a significantly longer progression free survival (5.7 versus 3.9 months, $\mathrm{p}=0.001$ ) and overall survival (12.1 versus 9.3 months, $\mathrm{p}=0.02)$ when compared to cisplatin alone (21).

Several studies have observed tumour response rates of between 16-48\% for gemcitabine used in combination with cisplatin (23-25). Three patients from our study received cisplatin in combination with gemcitabine. There was a trend for shorter overall survival for these patients receiving cisplatin with gemcitabine when compared to other regimens, although the difference was not statistically significant (mean 13.2 vs. 21.2 months, $\mathrm{p}=0.59$ ).

Another chemotherapy regimen described in the literature discloses a response rate of $26 \%$ when gemcitabine is used in combination with carboplatin (26). According to available data, this combination has lower response rates than a combination of gemcitabine and cisplatin.

In the literature there are few articles about topotecan administration for patients with mesothelioma. In a study of patients evaluated with unresectable tumours, the topotecan administered for palliative purposes reported no objective responses with 18 patients having stable disease for a median of 74 days. The median survival for all patients was 230 days, with $23 \%$ alive at 1 year (27).

One patient from our study received six cycles of topotecan as a second line treatment, after which chemotherapy was continued in a third line with liposomal doxorubicin, docetaxel and etoposide. In a study of 33 patients receiving lyposomal doxorubicin, 31 patients were evaluable for response and only two patients had a partial response with a median survival of 13 months for all the study patients (28). One patient with a variety of repeated chemotherapy cycles had an overall survival of 100 months. That may indicate the efficacy of repeated 
chemotherapy cycles despite the tumour progression. A variety of chemotherapeutic regimens and administration routes with corresponding survival rates are displayed in Table 2.

Of the five patients with a cytoreductive score for completeness of 2 or higher there was available information regarding only two patients, of whom one was dead and another was still alive after 23 months from diagnosis.

\section{Conclusion}

Because of the low number of patients and different treatment approaches, data from a particular patient setting are inconclusive, but from the literature there is evidence that patients with malignant intraperitoneal mesothelioma should undergo optimal cytoreduction and receive a combination of cisplatin and pemetrexed as a first line chemotherapy for intravenous or cisplatin in different chemotherapy regimens using the intraperitoneal administration route, if accessible, with even higher overall survival rates.

\section{Acknowledgements}

The study was performed during a fellowship exchange program with the support of the European Society of Gynecological Oncology. The clinical exchange program was organized during $\mathrm{PhD}$ studies owing to a project for $\mathrm{PhD}$ studies promotion in Latvia (P.Stradins University project number: 2009/0147/1DP/ 1.1.2.1.2/09/IPIA/ VIAA/009) and Latvian University project for early cancer diagnostics (project number: 2009/0220/1DP/1.1.1.2.0/09/APIA/VIAA/016).

\section{Conflict of interest}

No conflict of interest was declared by the authors.

Table 2. Summary of trials reflecting different chemotherapeutic agents, route of administration, overall (OS), disease free survival (DFS) and ongoing trials

\begin{tabular}{|c|c|c|c|c|c|c|c|c|c|}
\hline Study & $\begin{array}{c}\text { Patients } \\
\mathbf{n}\end{array}$ & $\begin{array}{c}\text { Route of } \\
\text { administration }\end{array}$ & $\begin{array}{l}\text { Chemotherapeutic } \\
\text { agents and patients } \\
\text { in study arms }\end{array}$ & $\begin{array}{c}\text { Median OS, } \\
\text { months }\end{array}$ & $\begin{array}{c}\text { Median DFS, } \\
\text { months }\end{array}$ & $\begin{array}{l}\text { 1-year } \\
\text { survival }\end{array}$ & $\begin{array}{l}\text { 2-year } \\
\text { survival }\end{array}$ & $\begin{array}{l}\text { 3-year } \\
\text { survival }\end{array}$ & $\begin{array}{l}\text { 5-year } \\
\text { survival }\end{array}$ \\
\hline $\begin{array}{l}\text { Vogelzang et al., } \\
2003(21)\end{array}$ & 456 & I.V. & $\begin{array}{l}\text { Pemetrexed+ } \\
\text { Cisplatin (226) } \\
\text { Cisplatin (222) }\end{array}$ & $\begin{array}{l}12.1 \\
9.3\end{array}$ & $\begin{array}{l}5.7 \\
3.9\end{array}$ & $\begin{array}{l}50.3 \% \\
38.0 \%\end{array}$ & - & - & - \\
\hline $\begin{array}{l}\text { Feldman et al., } \\
2003(28)\end{array}$ & 49 & HIPEC & $\begin{array}{c}\text { Cisplatin+ } \\
\text { Fluorouracil+ } \\
\text { Paclitaxel }\end{array}$ & 92.0 & 17.0 & $86.0 \%$ & $77.0 \%$ & $59.0 \%$ & $59.0 \%$ \\
\hline $\begin{array}{l}\text { Jänne et al., } \\
2005 \text { (29) }\end{array}$ & 73 & I.V. & $\begin{array}{c}\text { Pemetrexed (32) } \\
\text { Pemetrexed+ } \\
\text { Cisplatin (66) }\end{array}$ & $\begin{array}{c}8.7 \\
13.1\end{array}$ & $\begin{array}{l}- \\
-\end{array}$ & $\begin{array}{c}0.0 \% \\
66.0 \%\end{array}$ & - & $\begin{array}{l}- \\
-\end{array}$ & - \\
\hline $\begin{array}{l}\text { Yan et al., } \\
2006(30)\end{array}$ & 62 & HIPEC+EPIC & $\begin{array}{c}\text { Cisplatin+ } \\
\text { Doxorubicin+ } \\
\text { Paclitaxel }\end{array}$ & 79.0 & $\begin{array}{l}- \\
-\end{array}$ & $84.0 \%$ & - & $58.0 \%$ & $50.0 \%$ \\
\hline $\begin{array}{l}\text { Yan et al., } \\
2006(20)\end{array}$ & 100 & HIPEC+EPIC & $\begin{array}{c}\text { Cisplatin+ } \\
\text { Doxorubicin+ } \\
\text { Paclitaxel }\end{array}$ & 52.0 & & $78.0 \%$ & $64.0 \%$ & $55.0 \%$ & $46.0 \%$ \\
\hline $\begin{array}{l}\text { Elias et al., } \\
2007 \text { (31) }\end{array}$ & 22 & HIPEC & $\begin{array}{c}\text { Oxaliplatin (10) } \\
\text { Oxaliplatin+ } \\
\text { Irinotecan (12) }\end{array}$ & 100.0 & 40.0 & $88.0 \%$ & $83.0 \%$ & $68.0 \%$ & $63.0 \%$ \\
\hline $\begin{array}{l}\text { Simon et al., } \\
2008 \text { (22) }\end{array}$ & 20 & I.V. & $\begin{array}{c}\text { Pemetrexed+ } \\
\text { Gemcitabine }\end{array}$ & 26.8 & - & $67.5 \%$ & $50.0 \%$ & - & - \\
\hline $\begin{array}{l}\text { Hesdorffer et al., } \\
2008(32)^{*}\end{array}$ & 27 & HIPEC+I.V. & $\begin{array}{l}\text { Cisplatin+ } \\
\text { Mitomicin+ } \\
\text { Doxorubicin }\end{array}$ & 70.0 & - & - & - & $67.0 \%$ & - \\
\hline $\begin{array}{l}\text { Carteni et al., } \\
2009 \text { (33) }\end{array}$ & 109 & I.V. & $\begin{array}{c}\text { Pemetrexed (38) } \\
\text { Pemetrexed+ } \\
\text { Cisplatin (37) } \\
\text { Pemetrexed+ } \\
\text { Carboplatin (34) }\end{array}$ & $\begin{array}{c}10.3 \\
-\end{array}$ & $\begin{array}{c}6.2 \\
-\end{array}$ & $\begin{array}{l}41.5 \% \\
57.4 \%\end{array}$ & $\begin{array}{l}- \\
-\end{array}$ & $\begin{array}{l}- \\
-\end{array}$ & $\begin{array}{l}- \\
-\end{array}$ \\
\hline $\begin{array}{l}\text { Blackham et al., } \\
2010 \text { (34) }\end{array}$ & 34 & HIPEC & $\begin{array}{c}\text { Mitomycin (19) } \\
\text { Cisplatin (15) }\end{array}$ & $\begin{array}{l}10.8 \\
40.8\end{array}$ & $\begin{array}{c}8.3 \\
10.6\end{array}$ & $\begin{array}{l}47.0 \% \\
80.0 \%\end{array}$ & $\begin{array}{l}47.0 \% \\
80.0 \%\end{array}$ & $\begin{array}{l}42.0 \% \\
80.0 \%\end{array}$ & $\begin{array}{c}16.0 \% \\
-\end{array}$ \\
\hline
\end{tabular}




\section{References}

1. Busch JM, Kruskal JB, Wu B. Armed Forces Institute of Pathology. Best cases from the AFIP. Malignant peritoneal mesothelioma. Radiographics 2002; 22: 1511-5. [CrossRef]

2. Antman KH, Pomfret EA, Aisner J, MacIntyre J, Osteen RT, Greenberger JS. Peritoneal mesothelioma: natural history and response to chemotherapy. J Clin Oncol 1983; 1: 386-91.

3. Asbestos, asbestosis, and cancer: the Helsinki criteria for diagnosis and attribution. Scand J Work Environ Health 1997; 23: 311-6.

4. Driscoll TR, Baker GJ, Daniels S, Lee J, Thompson R, Ferguson DA, et al. Clinical aspects of malignant mesothelioma in Australia. Aust NZJ Med 1993; 23: 19-25.

5. Legha SS, Muggia FM. Pleural mesothelioma: clinical features and therapeutic implications. Ann Intern Med 1977; 87: 613-21.

6. Vianna NJ, Maslowsky J, Roberts S, Spellman G, Patton RB. Malignant mesothelioma; epidemiologic patterns in New York State. N Y State J Med 1981; 81: 735-8.

7. Asensio JA, Goldblatt P, Thomford NR. Primary malignant peritoneal mesothelioma. A report of seven cases and a review of the literature. Arch Surg 1990; 125: 1477-81.

8. Reuter K, Raptopoulos V, Reale F, Krolikowski FJ, D'Orsi CJ, Graham S, et al. Diagnosis of peritoneal mesothelioma: computed tomography, sonography, and fine-needle aspiration biopsy. AJR Am J Roentgenol 1983; 140: 1189-94.

9. Sebbag G, Yan H, Shmookler BM, et al. Results of treatment of 33 patients with peritoneal mesothelioma. Br J Surg 2000; 87: 1587-93.

10. Zellos LS, Sugarbaker DJ. Diffuse malignant mesothelioma of the pleural space and its management. Oncology 2002; 16: 907-25. [CrossRef]

11. Hotta T, Taniguchi K, Kobayashi Y, Johata K, Sahara M, Naka T, et al. Chemotherapy and serum hyaluronic acid levels in malignant peritoneal mesothelioma. Hepatogastroenterology 2004; 51: 1073-83.

12. Le DT, Deavers M, Hunt K, Malpica A, Verschraegen CF. Cisplatin and irinotecan (CPT-11) for peritoneal mesothelioma. Cancer Invest 2003; 21: 682-9. [CrossRef]

13. Sebbag G, Sugarbaker P. Peritoneal mesothelioma proposal for a staging system. European Journal of Surgical Oncology 2001; Volume 27, Issue 3, 223-4. [CrossRef]

14. Elmes PC, Simpson JC. The clinical aspects of mesothelioma. Q J Med 1976; 45: 427-49.

15. De Pangher Manzini V. Malignant peritoneal mesothelioma. Tumori $2005 ; 91: 1-5$

16. Vuković M, Krivokuća D, Moljević N. Malignant Peritoneal Mesothelioma: a Case Report. Acta Chir Belg 2009; 109: 408-10.

17. Naka H, Naka A. Clinicopathological study of 100 Japanese patients with peritoneal mesothelioma in Japan. Gan No Rinsho 1984; 30: 1-10.

18. Moertel CG. Peritoneal mesothelioma. Gastro-enterology 1972; 63: 346-50.

19. Taub RN, Keohan ML, Chabot JC, Fountain KS, Plitsas M. Peritoneal mesothelioma. Curr Treat Options Oncol 2000; 1: 303-12. [CrossRef]

20. Yan TD, Yoo D, Sugarbaker PH. Significance of lymph node metastasis in patients with diffuse malignant peritoneal mesothelioma. Eur J Surg Oncol 2006; 32: 948-53. [CrossRef]
21. Vogelzang NJ, Rusthoven JJ, Symanowski J, Denham C, Kaukel E, Ruffie P, et al. Phase III study of pemetrexed in combination with cisplatin versus cisplatin alone in patients with malignant pleural mesothelioma. J Clin Oncol 2003; 21: 2636-44. [CrossRef]

22. Simon GR, Verschraegen CF, Jänne PA, Langer CJ, Dowlati A, Gadgeel SM, et al. Pemetrexed plus gemcitabine as firstline chemotherapy for patients with peritoneal mesothelioma: Final report of a phase II trial. Journal of Clinical Oncology 2008; 26: 3567-72. [CrossRef]

23. Favaretto AG, Aversa SM, Paccagnella A, et al. Gemcitabine combined with carboplatinin patients with malignant pleural mesothelioma: a multicentric phase II study. Cancer 2003; 97: 2791-7. [CrossRef]

24. Maksymiuk AW, Marschke RF Jr, Tazelaar HD, et al. Phase II trial of topotecan for the treatment of mesothelioma.Am J Clin Oncol 1998; 21: 610-3. [CrossRef]

25. Baas $\mathrm{P}$, van Meerbeeck $\mathrm{J}$, Groen $\mathrm{H}$, Schouwink $\mathrm{H}$, Burgers $\mathrm{S}$, Daamen S, et al. Caelyx ${ }^{\mathrm{TM}}$ in malignant mesothelioma: A phase II EORTC study. Annals of Oncology 2000; 6: 697-700. [CrossRef]

26. Hunt KJ, Longton G, Williams MA, Livingston RB. Treatment of Malignant Mesothelioma With Methotrexate and Vinblastine, With or Without Platinum Chemotherapy. CHEST 1996; 5: 1239-42. [CrossRef]

27. Sørensen PG, Bach F, Bork E, Hansen HH. Randomized trial of doxorubicin versus cyclophosphamide in diffuse malignant pleural mesothelioma. Cancer Treat Rep 1985; 69: 1431-2.

28. Feldman AL, Libutti SK, Pingpank JF, Bartlett DL, Beresnev TH, Mavroukakis SM, et al. Analysis of factors associated with outcome in patients with malignant peritoneal mesothelioma undergoing surgical debulking and intraperitoneal chemotherapy. J Clin Oncol 2003; 21: 4560-7. [CrossRef]

29. Jänne PA, Wozniak AJ, Belani CP, Keohan ML, Ross HJ, Polikoff JA, et al. Open-label study of pemetrexed alone or in combination with cisplatin for the treatment of patients with peritoneal mesothelioma: outcomes of an expanded access program. Clin Lung Cancer 2005; 7: 40-6. [CrossRef]

30. Yan TD, Brun EA, Cerruto CA, Haveric N, Chang D, Sugarbaker $\mathrm{PH}$. Prognostic indicators for patients undergoing cytoreductive surgery and perioperative intraperitoneal chemotherapy for diffuse malignant peritoneal mesothelioma. Ann Surg Oncol 2007; 14: 41-9.

31. Elias D, Bedard V, Bouzid T, Duvillard P, Kohneh-Sharhi N, Raynard $\mathrm{B}$, et al. Malignant peritoneal mesothelioma: treatment with maximal cytoreductive surgery plus intraperitoneal chemotherapy. Gastroenterol Clin Biol 2007; 31: 784-8.

32. Hesdorffer ME, Chabot JA, Keohan ML, Fountain K, Talbot S, Gabay M, et al. Combined resection, intraperitoneal chemotherapy, and whole abdominal radiation for treatment of malignant peritoneal mesothelioma. American Journal of Clinical Oncology 2008; 31: 49-54. [CrossRef]

33. Carteni G, Manegold C, Garcia GM, et al. Malignant peritoneal mesothelioma-Results from the International Expanded Access Program using pemetrexed alone or in combination with a platinum agent. Lung Cancer 2009; 64: 211-8. [CrossRef]

34. Blackham AU, Shen P, Stewart JH, Russell GB, Levine EA. Cytoreductive Surgery with Intraperitoneal Hyperthermic Chemotherapy for Malignant Peritoneal Mesothelioma: Mitomycin Versus Cisplatin. Ann Surg Oncol 2010; 17: 2720-7. [CrossRef] 